\title{
The Effect Of Meloxicam and Mefenamic Acid Premedication on Pain Experience In Orthodontic Patients
}

\author{
Asem A. M. Abdaljawwad
}

B.D.S: Msc, Assistant lecturer, Orthodontist, Department of POP, College of Dentistry, University of Al-Anbar).

Zena Hekmat Al Taee

B.D.S: Msc , lecturer, Orthodontist, Department of POP, $\bar{C}$ ollege of Dentistry, University of Al-Anbar

Lamia Ibrahim Sood

B.D.S: Msc , lecturer, Department of POP, College of Dentistry, University of Al-Anbar

\begin{abstract}
Background: One of the side effects of orthodontic treatment is pain this lead to discourage patients from treatment. The aim of this study to estimate and compare the effect of preoperative use of Meloxicam and Mefenamic acid drug on pain experienced after separator placement in orthodontic patients.

Materials and Methods: Thirty patients aged between 17 and 26 years who claimed to undergo orthodontic treatment with fixed appliance were participate in this double-blind, prospective study. They were randomly distributed into three experimental groups, 10 for each group as follow: group A; administration of starch capsules, group B; administration of 500 mg mefenamic acid, and group C; administration of $7.5 \mathrm{mg}$ meloxicam; medications were administered 1 hour before separator placement. The pain was recorded by the patients on a linear and graded Visual Analogue Scale (VAS) at time intervals of 2 hours, 6 hours, nighttime on the day of appointment, 24 hours after the appointment, and 48 hours after the appointment during each of these four activities: (chewing, biting, fitting front teeth, and fitting back teeth).

Result: The results of ANOVA reveal high significant differences between the three experimental groups at all time intervals and during all four activities $(P<.05)$. LSD comparisons reveal high significant differences between placebo, mefenamic acid, and meloxicam groups $(P<.05)$ the lowest pain was reported by the meloxicam group, and the highest one in placebo group.

Conclusion:

- The use of $7.5 \mathrm{mg}$ meloxicam tab or drug as a single dose 1 hour preoperatively only is highly recommended for pain control after separator placement.

-The pain begins at the moment of separator placement and reaches its peak in 24 hours and then, gradually decreases until the 48 hours.
\end{abstract}

\section{KEY WORD}

Orthodontic pain. Mefenamic acid. Meloxicam

\section{INTRODUCTION}

Approximately $90 \%$ of the Orthodontic patients report pain ${ }^{[1]}$, making it the most commonly reported detrimental effect of Orthodontic treatment and the greatest reason for wanting to discontinue or avoid orthodontic care ${ }^{[2.3]}$

Pain is caused by some tissue changes. These tissue changes in orthodontic treatment are caused by the compression of periodontal ligament and alteration of blood flow to the tooth, resulting in releasing chemical mediators like prostaglandins ${ }^{[4,5}$, 6].

It has been claimed that degree of pain experienced by patient varies based on gender, age, patient anxiety level, and emotional stress ${ }^{[1,6,7,8]}$. When compared with the pain associated with extractions, both the incidence and severity of orthodontic pain is perceived to be greater ${ }^{[6,9]}$

The conventional nonsteroidal anti-inflammatory drugs (NSAIDs) like Mefanamic acid, ibuprofen, piroxicam, aspirin and naproxen sodium produce their analgesic, antipyretic and anti-inflammatory effect by blocking the production of prostaglandins through inhibiting the other isoforms of cyclooxygenase $(\mathrm{COX})$ enzyme ${ }^{[10]}$ these medications are called non- selective COX inhibitors, since they block both $\mathrm{COX}_{1}$ and $\mathrm{COX}_{2}$ isoforms ${ }^{[11]}$.

Meloxicam is one of most popular relatively selective $\mathrm{COX}_{2}$ inhibitors used in the treatment of acute and chronic inflammatory painful disorders like rheumatoid arthritis, dental pain, and postoperative pain ${ }^{[12-14]}$. It is now clear that meloxicam has a lower gastric effect compared to other NSAIDs ${ }^{[13]}$. Efficacy of this drug in controlling post-endodontic pain and pain after third molar removal and oral surgery has been investigated previously ${ }^{[13.14 .15]}$.

The aim of this study is to estimate and compare the effect of preoperative use of Meloxicam and Mefenamic acid on pain experienced after separator placement in orthodontic patients.

We think this kind of information is necessary in clinical practice, enabling the health care professionals to consider all the factors related to the orthodontic treatment, and to decide on the best individual therapeutic plan for each case.

\section{MATERIALS AND METHODS:}

The study was conducted in Baghdad. The sample comprised of 30 patients (15 males and 15 females) who were scheduled to receive fixed 
orthodontic treatment agreed to be part of this study. The selection criteria were: the patient must be (1) not younger than 15 years and not older than 30 years of age; (2) never have any previous orthodontic treatment; (3) have no contraindications or adverse effects related to mefenamic acid and meloxicam; (4) not using any antibiotics or other analgesics during conducting the study; and (5) have a minimum weight requirement of 40 kilograms, as per Food and Drug Administration- approved over-the-counter pediatric dosage labeling guidelines.

Ten patients were evenly and randomly distributed to the three experimental groups as follow; group A (starch capsule), group B (500mg mefenamic acid), and group $\mathrm{C}$ (7.5mg meloxicam). For all groups, medications were administrated one hour prior to separator placement as one tablet.

A $100-\mathrm{mm}$ horizontal visual analogue scale (VAS) was selected to measure the degree of discomfort ${ }^{[17]}$ and was given to the patients in the form of a 6 pages booklet with possible answers of "no pain" $(0 \mathrm{~mm})$ and "worst pain" $(100 \mathrm{~mm})$. The patients were instructed to mark the degree of pain/ discomfort at the appropriate time intervals by placing a mark on the scale and indicating the severity of pain/ discomfort during four different activities: biting, chewing, fitting back teeth together, and fitting front teeth together. These were recorded by the patients at the following intervals: 2 hours post treatment; 6 hours post treatment; bedtime/nighttime on the day of the appointment; 24 hours after the appointment; and 48 hours after the appointment.

\section{Statistical analysis}

All Statistical analyses were done using the Statistical Package for Social Sciences (Version 22.0, SPSS Inc., Chicago, Illinois, USA). Descriptive analyses were performed for pain scores for the experimental groups at each time intervals. Comparison between the three experimental groups in the four activities was made using one way analysis of variance (ANOVA). If the results of ANOVA were significant, least significant difference (LSD) test was used to find any statistical significant difference between each two groups. The level of significance for all tests in our study was set at $p<0.05$.

\section{RESULTS}

From this study; descriptive statistics for the experimental groups are given in table 1 . The mean age of the subjects in the three experimental groups was 22.14 , and there was no significant difference between their mean ages $(P<.5)$.

Table 1: Experimental Groups with Preoperative Analgesic, Mean Age, and Sex Distribution

\begin{tabular}{|c|c|c|c|c|c|}
\hline Group & $\begin{array}{l}\text { Preoperative } \\
\text { medication }\end{array}$ & Drug dose & Mean age & $\begin{array}{c}\text { Std. Devia- } \\
\text { tion }\end{array}$ & $\begin{array}{c}\text { Gender } \\
\text { Male/Female }\end{array}$ \\
\hline A & placebo & 1 Capsule & 22.13 & 3.22 & $5 / 5$ \\
\hline B & $\begin{array}{c}\text { Mefenamic } \\
\text { acid }\end{array}$ & $500 \mathrm{mg}$ & 21.29 & 1.59 & $5 / 5$ \\
\hline $\mathrm{C}$ & Meloxicam & $7.5 \mathrm{mg}$ & 23.00 & 2.00 & $5 / 5$ \\
\hline
\end{tabular}

Differences in Pain score between experimental Groups in "Pain on biting":

The results of ANOVA reveal highly significant differences $(P<0.001)$ among the placebo, mefenamic acid and meloxicam groups and a significant different in the time interval ,2 hours post treatment; 6 hours post treatment; bedtime/nighttime on the day of the appointment; 24 hours after the appointment; and 48 hours after the appointment.

Patients who were administered meloxicam experienced less "pain on biting compared with patients in the placebo group $(P<0.001)$ (Figure 1; Table 2). 
Table 2: The mean, standard deviation and $p$ value of pain level in different conditions

\begin{tabular}{|c|c|c|c|c|c|c|c|c|c|c|c|}
\hline \multicolumn{12}{|c|}{ Biting } \\
\hline $\begin{array}{l}\text { Experimen- } \\
\text { tal Groups }\end{array}$ & $\begin{array}{c}2 h \\
\text { mean }\end{array}$ & SD & $\begin{array}{c}6 h \\
\text { mean }\end{array}$ & SD & $\begin{array}{c}\text { At } \\
\text { night } \\
\text { mean }\end{array}$ & $S D$ & $\begin{array}{c}24 h \\
\text { mean }\end{array}$ & SD & $\begin{array}{c}48 h \\
\text { mean }\end{array}$ & SD & Pvalue \\
\hline $\begin{array}{c}\text { Group A: } \\
\text { placebo }\end{array}$ & 63.8 & 4.21 & 67.7 & 3.13 & 73.3 & 3.65 & 76.5 & 3.98 & 65.6 & 4.65 & \multirow{4}{*}{$0.000^{*}$} \\
\hline $\begin{array}{l}\text { Group B: } \\
\text { mefenamic } \\
\text { acid }\end{array}$ & 32.9 & 2.85 & 54.3 & 3.40 & 60.5 & 3.37 & 70.2 & 3.74 & 55.0 & 2.98 & \\
\hline $\begin{array}{l}\text { Group C: } \\
\text { meloxicam }\end{array}$ & 15.5 & 1.90 & 43.0 & 3.80 & 49.9 & 4.56 & 51.5 & 2.64 & 39.0 & 4.22 & \\
\hline P value & \multicolumn{10}{|c|}{$0.000 *$} & \\
\hline \multicolumn{11}{|c|}{ Chewing } & \\
\hline $\begin{array}{l}\text { Experimen- } \\
\text { tal Groups }\end{array}$ & $\begin{array}{c}2 h \\
\text { mean }\end{array}$ & SD & $\begin{array}{c}6 h \\
\text { mean }\end{array}$ & SD & $\begin{array}{c}\text { At } \\
\text { night } \\
\text { mean }\end{array}$ & $S D$ & $\begin{array}{c}24 h \\
\text { mean }\end{array}$ & SD & $\begin{array}{c}48 h \\
\text { mean }\end{array}$ & $S D$ & Pvalue \\
\hline $\begin{array}{c}\text { Group A: } \\
\text { placebo }\end{array}$ & 41.5 & 4.12 & 57.20 & 3.46 & 62.4 & 4.27 & 66.7 & 3.83 & 60.5 & 3.03 & \multirow{4}{*}{$0.000 *$} \\
\hline $\begin{array}{l}\text { Group B: } \\
\text { mefenamic } \\
\quad \text { acid }\end{array}$ & 30.4 & 3.95 & 46.2 & 3.52 & 57.2 & 3.61 & 54.6 & 3.60 & 49.7 & 3.65 & \\
\hline $\begin{array}{l}\text { Group C: } \\
\text { meloxicam }\end{array}$ & 11.6 & 2.41 & 17.5 & 2.42 & 27.0 & 2.98 & 30.6 & 2.67 & 22.6 & 3.17 & \\
\hline$P$ value & \multicolumn{10}{|c|}{$0.000 *$} & \\
\hline \multicolumn{12}{|c|}{ Fitting the front teeth } \\
\hline $\begin{array}{l}\text { Experimen- } \\
\text { tal Groups }\end{array}$ & $\begin{array}{c}2 h \\
\text { mean }\end{array}$ & SD & $\begin{array}{c}6 h \\
\text { mean }\end{array}$ & SD & $\begin{array}{c}\text { At } \\
\text { night } \\
\text { mean }\end{array}$ & $S D$ & $\begin{array}{c}24 h \\
\text { mean }\end{array}$ & SD & $\begin{array}{c}48 h \\
\text { mean }\end{array}$ & SD & P value \\
\hline $\begin{array}{c}\text { Group A: } \\
\text { placebo }\end{array}$ & 48.4 & 5.13 & 68.5 & 4.74 & 75.4 & 3.95 & 76.4 & 5.89 & 72.4 & 5.72 & \multirow{4}{*}{$0.000^{*}$} \\
\hline $\begin{array}{l}\text { Group B: } \\
\text { mefenamic } \\
\text { acid }\end{array}$ & 30.0 & 3.50 & 50.1 & 3.21 & 66.4 & 2.41 & 72.1 & 2.33 & 61.0 & 3.33 & \\
\hline $\begin{array}{l}\text { Group C: } \\
\text { meloxicam }\end{array}$ & 13.7 & 3.06 & 20.2 & 2.90 & 38.9 & 4.15 & 42.9 & 4.75 & 38.2 & 4.76 & \\
\hline P value & \multicolumn{10}{|c|}{$0.000 *$} & \\
\hline \multicolumn{12}{|c|}{ Fitting the back teeth } \\
\hline $\begin{array}{l}\text { Experimen- } \\
\text { tal Groups }\end{array}$ & $\begin{array}{c}2 h \\
\text { mean }\end{array}$ & SD & $\begin{array}{c}6 h \\
\text { mean }\end{array}$ & SD & $\begin{array}{c}\text { At } \\
\text { night } \\
\text { mean }\end{array}$ & SD & $\begin{array}{c}24 h \\
\text { mean }\end{array}$ & SD & $\begin{array}{c}48 h \\
\text { mean }\end{array}$ & SD & Pvalue \\
\hline $\begin{array}{c}\text { Group A: } \\
\text { placebo }\end{array}$ & 44.0 & 7.38 & 62.2 & 6.48 & 63.2 & 6.70 & 62.4 & 6.19 & 47.7 & 4.45 & \multirow{4}{*}{$0.000 *$} \\
\hline $\begin{array}{l}\text { Group B: } \\
\text { mefenamic } \\
\quad \text { acid }\end{array}$ & 32.1 & 2.33 & 32.2 & 2.53 & 44.7 & 2.79 & 58.4 & 2.72 & 44.2 & 2.10 & \\
\hline $\begin{array}{l}\text { Group C: } \\
\text { meloxicam }\end{array}$ & 10.1 & 4.25 & 12.2 & 2.53 & 19.4 & 3.13 & 23.5 & 2.42 & 24.1 & 3.41 & \\
\hline P value & \multicolumn{10}{|c|}{$0.000 *$} & \\
\hline
\end{tabular}

*Highly significance $(\mathrm{P}<\mathbf{0 . 0 0 1})$ 


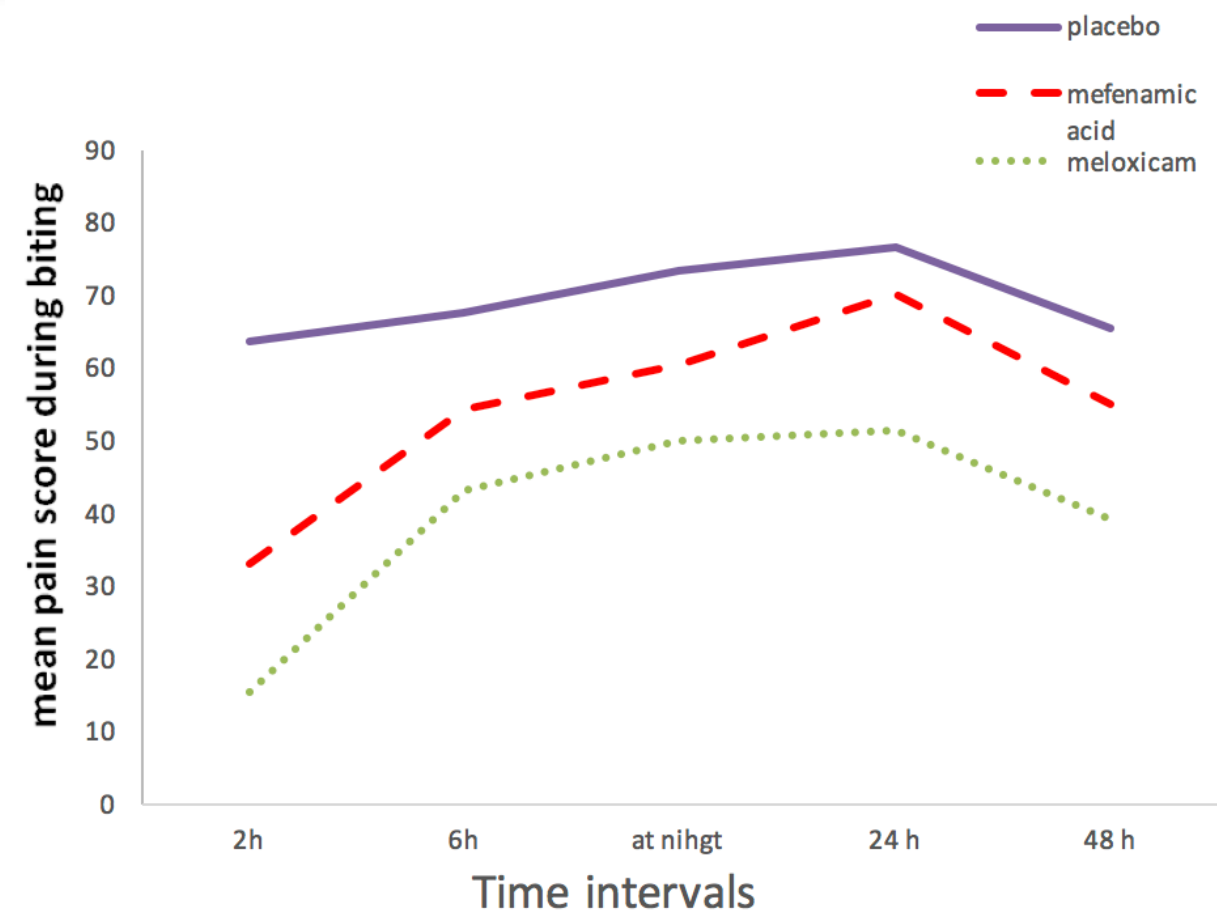

Fig. 1: Comparison of the mean pain scores on VAS among the three study groups over time on biting Differences in pain score between experimental hours, and 48 hours after the separator placement groups in "Pain on Chewing":

From Table 2; highly significant differences were shown among the placebo, mefenamic acid and meloxicam groups $(P<0.001)$ (Figure 2; Table 2). The pain scores at 2 hours, 6 hours, nighttime, 24 teeth.

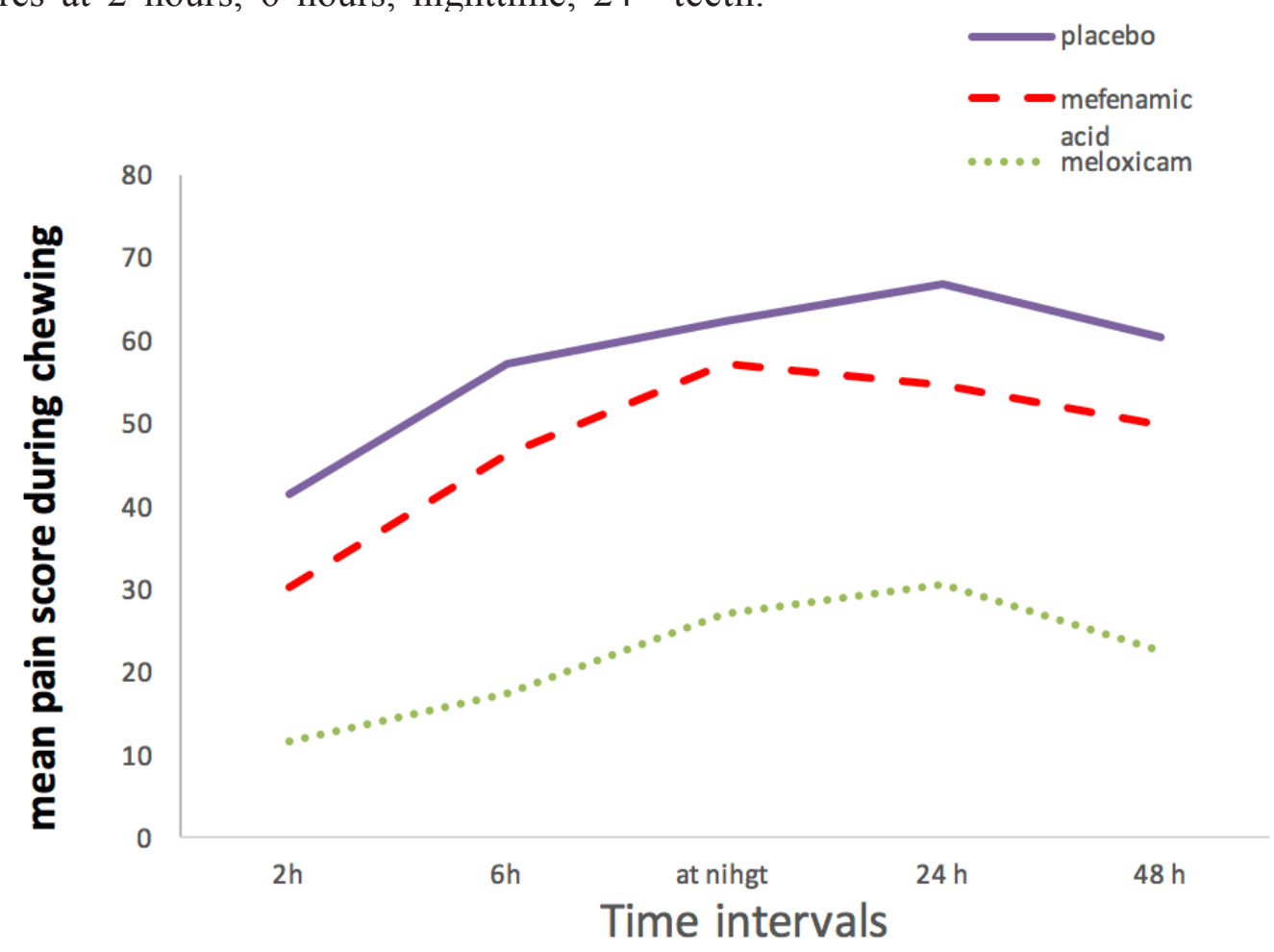

Fig. 2: Comparison of the mean pain scores on VAS among the three study groups over time on chewing Differences in Pain score between experimental time intervals. groups in "Pain on Fitting the front teeth"

With respect to pain level on fitting anterior teeth together, patients administered meloxicam showed highly significant $(P<0.001)$ less pain scores than mefenamic acid and placebo groups at all different appointment showed the meloxicam group to be the lowest among other experimental groups. This study showed the mean pain scores on chewing were less than on biting and more than on fitting front and back placebo acid .... meloxicam

This study showed the pain scores on fitting the front teeth was less than on during biting or chewing and more than on fitting posterior teeth (Figure 3; Table 2). 


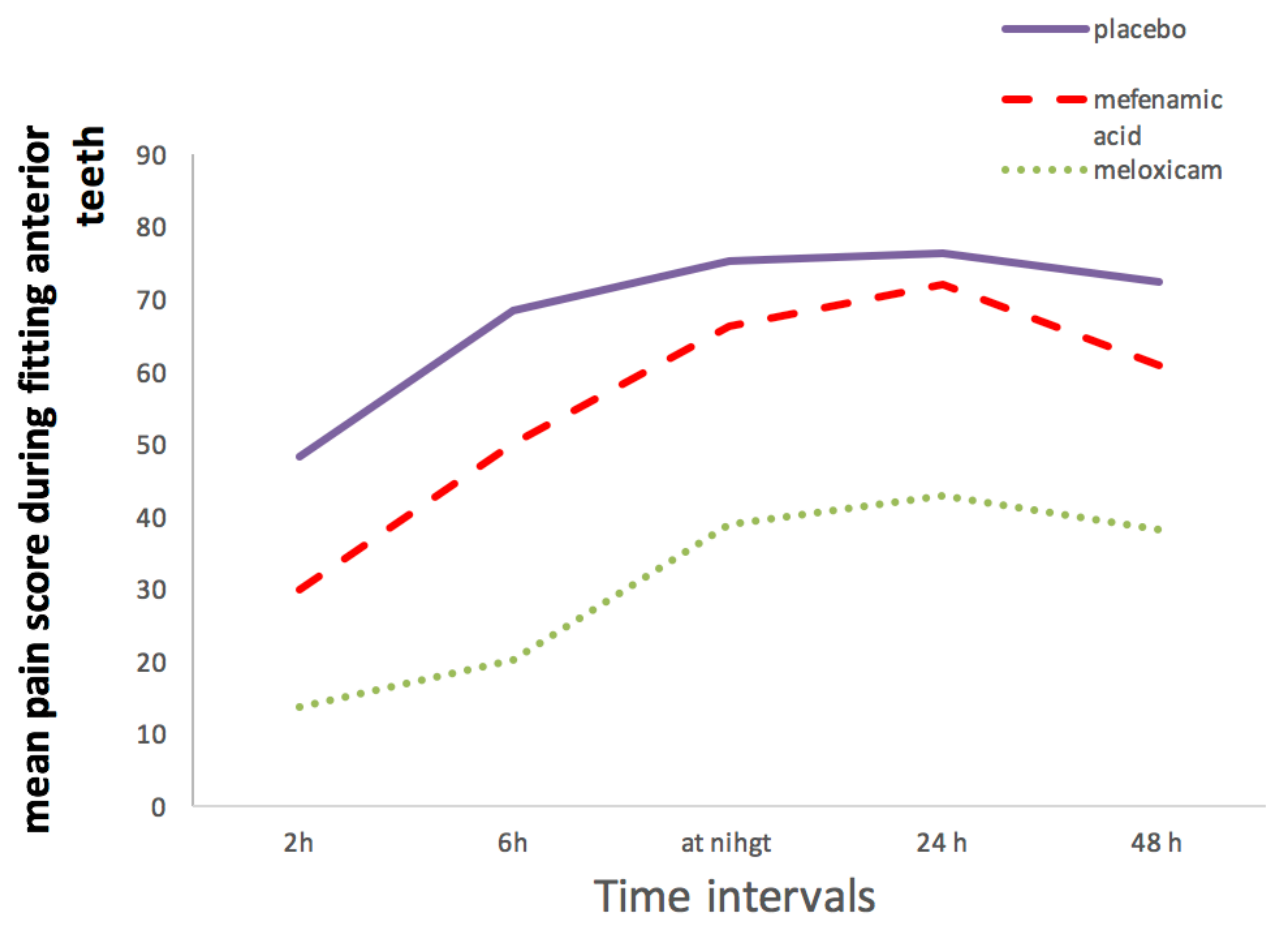

Fig. 3: Comparison of the mean pain scores on VAS among the three study groups over time on fitting the anterior teeth

Differences in Pain score between experimental groups in "Pain on Fitting the back teeth":

On measuring the differences in pain experienced on fitting the back teeth; the placebo group showed highly significant $(P<0.001)$ higher pain scores than the mefenamic acid and the meloxicam groups at all different time intervals, while the meloxicam group was with the least pain scores.

This study showed that the mean pain scores in fitting on the back teeth were less than other experimental group (Figure 4; Table 2).

Pain level in all three experimental groups increased gradually to reaches its peak level at 24 hours after separators placement, and then decreased gradually from the peak at 48 hours after separators placement.

At all-time intervals patients in the placebo group showed the highest mean pain scores, while patients on meloxicam showed the lowest mean pain scores (Table 2).

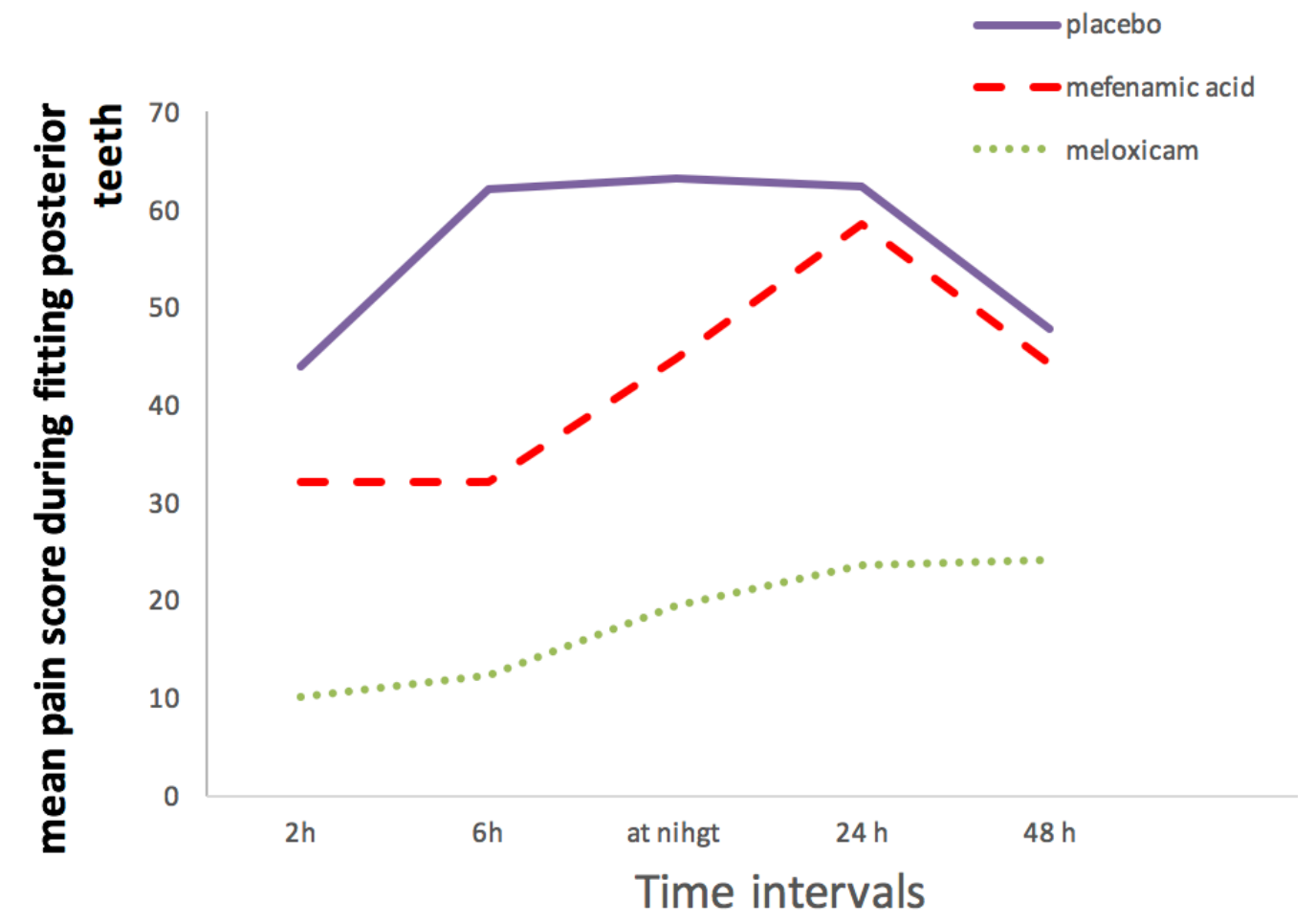

Fig. 4: Comparison of the mean pain scores on VAS among the three study groups over time on fitting the posterior teeth 


\section{DISCUSSION}

Pain relief in dentistry has been fairly well studied in the literatures but the management of pain in patients receive orthodontic treatment is less well known.

As clinicians we are always asked whether it will be benefit for the patients to take analgesics during orthodontic treatment or not. Some studies have shown that pretreatment doses of NSAIDs may help to reduce the amount of pain experienced immediately after treatment ${ }^{[18-20]}$.

This study was done with the aim to compare the efficacy of two analgesics, mefenamic acid and meloxicam in their standard doses in the management of orthodontic pain.as a preemptive analgesic one hour before the separator placement in the orthodontic patient.

In this study, the effect of preemptive administration of placebo, mefanamic acid, and meloxicam in controlling post-separator pain was evaluated and compared using visual analog scale (VAS). VAS is generally accepted to be the most reliable and accurate valid tool (instrument) for measuring acute and chronic pain, and is more sensitive for measuring positive responses to treatment compared to verbal descriptors [6,17,21].

Since the data and information in this study were collected by questionnaires, the questionnaire was translated from simple Arabic words to choice of the most suitable score in the visual analog scale (VAS).

The nature of pain caused by orthodontic treatment is not completely known. Dustman suggested that such a pain is caused by a combination of pressure, ischemia, inflammation and edema ${ }^{[5]}$

The results of this study show that pain levels increased from 2 hours to the maximum in the first 24 hours and then gradually declined from peak pain scores at 48 hours after separator placement. This finding is in accordance with those of previous investigations $[7,8,22,24,25,26]$.

Similar to other studies evaluating orthodontic pain level, the greatest reported pain occurred on biting and chewing rather than at fitting posterior teeth ${ }^{[22,25,25,26,27]}$.

This is because orthodontic pain occurs as a result of compression, inflammation, and edema in the periodontal ligament, and there is greater compression during function in the periodontal ligament (PDL) ${ }^{[7}$, 27].

The results of this study revealed that patients in the meloxicam group reported the lowest pain scores in various conditions and different times, which is significant until 48 hours after separator placement compared to the other groups. This finding may be due to the absorption, selectivity and the high bioavailability of the drug. Meloxicam has a long mean half-life and, hence, has a longer duration of action than mefenamic acid thus provided pain relief for a longer duration, until the second day ${ }^{[20]}$

There are two major concerns with using NSAIDs to manage orthodontic pain by inhibiting COX activity and thus prostaglandin production; one is that it may interfere with tooth movement, a number of animal studies ${ }^{[82,29]}$ have demonstrated decreased rates of tooth movement with NSAID administration. However, the use of NSAIDs is only of concern in chronic users and not when taken at modest doses over the 3-4 days following treatment. ${ }^{[1]}$ The other is their gastrointestinal side effects, meloxicam is a relatively $\mathrm{COX}$ inhibitor with more inhibitory effects on $\mathrm{COX}_{2}$ than $\mathrm{COX}_{1}$. Via this inhibitory effect on $\mathrm{COX}_{2}$, it could be effective in orthodontic pain control. In addition, $\mathrm{COX}_{1}$ inhibition is responsible for the adverse gastric effects of non-selective NSAIDs [30]. It has been shown that meloxicam doses $\leq 15 \mathrm{mg}$ decreased the incidence of gastrointestinal side effects such as perforation, ulceration, and bleeding than non-selective NSAIDs ${ }^{[31]}$.

There has been an increased concern regarding the risk of cardiovascular thrombotic event associated with the administration of selective NSAIDs [13, 24]. However, it seems that meloxicam is relatively safer compared to other medications of this class of NSAIDs; specifically in lower doses such as what was used in the current study (a single $7.5 \mathrm{mg}$ ), the risk of cardiovascular events may be very low ${ }^{[15,32]}$, So current study allowed us to state that meloxiam appears to be an analgesic of choice for orthodontic pain.

\section{CONCLUSIONS}

- Preoperative administration of $7.5 \mathrm{mg}$ meloxicam one hour before separator placement decreases pain significantly at 2 hours; 6 hours; nighttime; 24 hours; and 2 days after separator placement in comparison to mefenamic acid or placebo.

- The use of $7.5 \mathrm{mg}$ meloxicam as a single dose 1 hour preoperatively only is highly recommended for pain control after separator placement.

- The pain begins at the moment of separator placement and reaches its peak in 24 hours and then, gradually decreases until the 48 hours.

- The most severe pain was reported by patients during biting and the least on fitting on posterior teeth. 


\section{REFERENCES}

1. Scheurer P, Firestone A, Burgin W.Perception of pain as a result of Orthodontic treatment with fixed appliances . Eu r J or t h o d .1996; 18:349-357.

2. Oliver R, Knapman YM. Attitudes to Orthodontic treatment. Br J Orthod.1985; 12:179-188.

3. Kapoor P., SinghH., Ghai G. and Ghai G.Perception Of Pain And Discomfort From Three Types Of Orthodontic Separators. Indian Journal of Dental Sciences.2013; (5): 2231-2293

4. Krishnan V. Orthodontic pain: from cause to management-a review. Eur J Orthod. 2007; 29:170-79.

5. Furstman L, Bernik S. Clinical considerations of the periodontium. Am J Orthod. 1972; 61:138-55.

6. Najafi H., Oshagh M. , Salehi P., Babanouri N. and Torkan S. Comparison of the effects of preemptive acetaminophen, ibuprofen, and meloxicam on pain after separator placement: a randomized clinical trial Progress in orthodontics. 2015; 16-34.

7. Ngan P, Kess B, Wilson S. Perception of discomfort by patients undergoing orthodontic treatment. Am J Orthod Dentofacial Orthop. 1989;96:47-53.

8. Brown DF, Moerenhout RG. The pain experience and psychological adjustment to orthodontic treatment of preadolescents, adolescents, and adults. Am J Orthod Dentofacial Orthop. 1991;100:394-56.

9. Jones ML, Chan C. Pain in the early stages of orthodontic treatment. J Clin Orthod 1992;26:311-3.

10. Dionne RA, Berthold CW. Therapeutic uses of non-steroidal anti-inflammatory drugs in dentistry. Crit Rev Oral Biol Med. 2001;12:315-30.

11. Jackson LM, Hawkey CJ. COX-2 selective nonsteroidal antiinflammatory drugs, do they really offer any advantages? Drugs. 2000;59:1207-16.

12. Bruno MB, Bruno MA, Krymchantowski AV, da Motta AF, Mucha JN. A double-blind, randomized clinical trial assessing the effects of a single dose of preemptive antiinflammatory treatment in orthodontic pain. Prog Orthod. 2011;12:2-7.

13. Euller-Ziegler L, Velicitat P, Bluhmki E, Turcy D, Scheuerer $\mathrm{S}$, Combe B. Meloxicam: a review of its pharmacokinetics; efficacy and tolerability following intramuscular administration. Inflamm Res. 2001;50: 5-9.

14. Calvo AM, Sakai VT, Giglio FPM, Modensa KCS, Colombini BL, Benetello V, et al. Analgesic and antiinflammatory dose-response relationship of 7.5 and $15 \mathrm{mg}$ meloxicam after lower third molar removal: a double blind, randomized, crossover study. Int J Oral MaxillofacSurg. 2007;36:26-31.

15. Aoki A, Yamaguchi H, Naito H, Shiiki K, Izawa K, Ota $\mathrm{Y}$, et al. Premedication with cyclooxygenase-2 inhibitor meloxicam reduced postoperative pain in patients after oral surgery. Int J Oral Maxillofac Surg. 2006;35:613-17.

16. Nekoofar MH, Sadeghipanah M, Dehpuor AR. Evaluation of meloxicam (a Cox-2 inhibitor) for management of postoperative endodontic pain: a double-blind placebocontrolled study. J Endod. 2003;29:634-37.
17. Sriwatanakul K, Kelvie W, Lasagna L, Calimlim JF, Weis OF, Mehta G. Studies with different types of visual analog scales for measurement of pain. Clin Pharmacol Ther. 1983; 34:234-239.)

18. Dionne RA, Cooper S. Evaluation of preoperative ibuprofen for postoperative pain after removal of third molars. Oral Surg Oral Med Oral Pathol 1978;45:851-6.

19. Dionne RA, Campbell RA, Cooper SA, Hall DL, Buckingham B. Suppression of postoperative pain by preoperative administration of ibuprofen in comparison to placebo,acetaminophen, and acetaminophen plus codeine. J Clin Pharmacol 1983;23:37-43.

20. Furst DE, Munster T. Nonsteroidal anti-inflammatory drugs, disease modifying anti rheumatic drugs, non-opioid analgesics and drugs used in gout. In: Katzung BG, editor. Basic and Clinical Pharmacology; 2001;8: 596-624.

21. Bergius M, Berggren U, Kiliaridis S. Experience of pain during an orthodontic procedure. Eur J Oral Sci. 2002;110: 92-98.

22. Steen Law SL, Southard KA, Law AS, Logan HL, Jakobsen JR. An evaluation of preoperative ibuprofen for treatment of pain associated with orthodontic separator placement. Am J Orthod Dentofacial Orthop. 2000;118:629-35.

23. Effectiveness of piroxicam and ibuprofen premedication on orthodontic patients' pain experiences a randomized control trial. Angle Orthod. 2011; 81:1097-1102.

24. Bernhardt MK, Southard KA, Batterson KD, Logan HL, Baker KA, Jakobsen JR. The effect of preemptive and/or postoperative ibuprofen therapy for orthodontic pain. Am J Orthod Dentofacial Orthop. 2001;120:20-7.

25. Ngan P, Wilson S, Shanfeld J, Amini H. The effect of ibuprofen on the level of discomfort in patient undergoing orthodontic treatment. Am J Orthod Dentofacial Orthop. 1994;106:88-95.

26. Farzanegan F, Zebarjad SM, Alizadeh S, Ahrari F. Pain reduction after initial arch wire placement in orthodontic patients. Am J Orthod Dentofacial Orthop. 2012;141:16973.

27. Young AN, Taylor RW, Taylor SE, Linnebur SA, Buschang PH. Evaluation of preemptive valdecoxibthrapy on initial arch wire placement discomfort in adults. Angle Orthod. 2006;76:251-59.

28. Walker JB, Buring SM. NSAID impairment of orthodontic tooth movement. Ann Pharmacother. 2001;35:113-115.

29. Kehoe MJ, Cohen SM, Zarrinnia K, Cowan A. The effect of acetaminophen, ibuprofen, and misoprostol on prostaglandin E2 synthesis and the degree and rate of orthodontic tooth movement. Angle Orthod. 1996;66:339349.

30. Proffit WR. Contemporary Orthodontics, 3rd ed. St Louis, Mo: Mosby; 2000:280-281.

31. Fleischmann R, Iqbal I, Slobodin G. Meloxicam. Expert Opin Pharmacother. 2002;3:1-12.

32. Asghar W, Jamali F. The effect of COX-2 selective meloxicam on myocardial, vascular and renal risks: a systemic review. Inflammopharmacology. 2015;23:1-16. 